\title{
The organization of basanite bifacial production at Giv'at Kipod Quarry, Israel: Towards an 'Alyawara Day’ model of extraction
}

\author{
Ron Shimelmitz ${ }^{1}$, Danny Rosenberg ${ }^{2}$ \\ 1. Zinman Institute of Archaeology, University of Haifa, 199 Abba Khousy Ave. Mount Carmel, Haifa, \\ 3498898, Israel. and The David Yellin Academic College of Education, 7 Maagal Beit Hamidrash St., Jerusalem \\ 91035, Israel. Email: rshimelmi@staff.haifa.ac.il \\ 2. Laboratory for Ground Stone Tools Research, Zinman Institute of Archaeology, University of Haifa, 199 \\ Abba Khousy Ave. Mount Carmel, Haifa, 3498898, Israel. Email: drosenberg@research.haifa.ac.il
}

\begin{abstract}
:
Hunter gatherers as well as farmers used a variety of lithic raw materials to shape their world, in which some were perceived as having symbolic or mythical content. While the anthropological literature demonstrates that the extraction of raw materials of special significance was often performed differently from that of other more 'ordinary' raw materials, identifying this in the archaeological record is difficult. In this paper we wish to shed new light on this topic using the Late Neolithic-Early Chalcolithic basanite bifacial tool production site of Giv at Kipod, Israel. In the southern Levant basalt axes and adzes have long been understood to embody greater symbolic content than the flint axes and adzes that dominate the Neolithic and Chalcolithic bifacial assemblages. By comparing the results from our excavations at the site of Giv'at Kipod to other production and extraction sites we exhibit how the organization of production was different than that related to the more common flint extraction in the region. While at most production and extractions sites the manufacture of various types of items is documented and the presence of tools, especially ad hoc tools, indicates that a variety of activities were performed at the locale of extraction, in the case of Giv'at Kipod the production was focused solely on the manufacture of bifacials with a marked lack of evidence of other significant activities. We attempt to provide guidelines to characterize different exploitation patterns between raw materials of varied social significance using these differences.
\end{abstract}

Keywords: ground stone tools, bifacials; basanite; Neolithic; quarry; Givªt Kipod; Southern Levant

\section{Introduction}

The role of raw material procurement in hunter-gatherer and early farming societies has been a topic of many studies. These refer to issues such as mobility patterns, trade and exchange, the perception of the landscape as well as to the mythical powers often relating to quarries (e.g., Hayden 1987; Darvill 1989; Cooney 1998; Le Roux 1998; Pétrequin et al. 1998; Özbek 2000; Wilson 2007; Risch 2011). Significantly, several ethnographic studies demonstrated that different raw material sources are often ascribed different meanings, which

Published by the School of History, Classics and Archaeology, University of Edinburgh ISSN: 2055-0472. URL: http://journals.ed.ac.uk/lithicstudies/

This work is licensed under a Creative Commons Attribution 2.5 UK: Scotland License. 
are associated with distinct procurement strategies (e.g., Binford \& O'Connell 1984; Taçon 1991; Brumm 2010).

Archaeologically, the importance of certain raw materials is often argued via the exploration of differences in their treatment and life-history compared to that of other raw materials exploited by the same population (e.g., Cauvin 1998; Healey 2001). While archaeological research invests considerable efforts to produce correlations between artefacts and specific outcrops of raw materials in the landscape (e.g., Campbell-Smith 1965; Gluhak \& Hofmeister 2009; Özbek 2011), we still know very little about how behavioural patterns and procurement strategies differed between the extraction of common raw material and raw materials of some "special" significance. In this paper we attempt to explore such differences through an in-depth investigation of the basanite bifacial production site of Giv'at Kipod, Menashe Hills, Israel, the only basaltic axe production site known in the Levant, and comparison to other flint workshops. Although bifacial tools, primarily axes and adzes, are widely considered to have been endowed with symbolic as well as utilitarian significance, it is often observed that the symbolic content varies greatly (e.g., Bradley \& Edmonds 1993: 53; Thomas \& Tilley 1993; Cooney 1998; Pétrequin et al. 1998). In the southern Levant, bifacials made of raw material other than flint, are repeatedly argued to bear greater symbolic weight (e.g., Rosen 1997: 97; Yerkes et al. 2003; Barkai 2005: 39-40).

Drawing on the results of our excavation, the organization of basalt bifacial production at the site of Giv'at Kipod (Shimelmitz et al. 2005; Rosenberg et al. 2008; Rosenberg \& Shimelmitz 2010), is reconstructed. By way of comparison with other quarry and production sites in the southern Levant, differences in the organization and exploitation of raw materials are then defined. It is argued that unlike other quarry sites, in which a wide range of tool types were produced (e.g., Wreschner 1963; Ronen \& Davis 1970; Gopher \& Barkai 2011; Nadel et al. 2011; however see Vardi 2015), the production sequences at Giv'at Kipod are indicative of solely of bifacial manufacture. Moreover, there is no evidence that any other activity took place at the site. Thus Giv'at Kipod represents a very specific and, in a sense, specialised field of practice. However, no evidence for standardization in morphology or size was noted, pointing away from specialized craft production (e.g., Costin 1991; 2005; Shafer \& Hester 1991; VanPool \& Leonard 2002). Using these differences we attempt to provide guidelines to characterize varied exploitation patterns between raw materials with different social significance.

\section{Raw material and bifacial tools in the southern Levant}

The geological landscape of the Levant is rich in flint outcrops scattered over most parts of the region with a distance of no more than a day walk from any point on the map (e.g., BarYosef 1991; Hovers 2001; Delage 2007). As such, the prevalence of flint among knapped stone tools is apparent already in the Lower Palaeolithic, with the exception of some of the earliest sites in the Levant, where basalt was also common (Bar-Yosef \& Goren-Inbar 1993; Goren-Inbar 2011). The intensive use of flint in the Levant probably reflects the greater control knappers could exert over the reduction process, and the sharper edges produced (e.g., Bar-Yosef 1994).

The exploitation of rock types other than flint intensified with the introduction of new production technologies during the Epipalaeolithic period, when ground stone tools made of basalt, limestone, and other raw materials became prevalent (e.g., Wright 1993; Rosenberg 2011; Rosenberg et al. 2012). Nevertheless, even in this period, flint clearly dominated the lithic assemblages (e.g., Shea 2013).

While within the Neolithic some artifacts were produced from specific raw material, such as sickle blades that were made from flint (e.g., Gopher 1989) and the Pre-Pottery Neolithic A 
(PPNA) bowls and platters that were made of limestone (Rosenberg 2008), other artifacts were made from a range of raw materials (e.g., Wright 1993; Rosenberg 2011). The use of a variety of raw materials to manufacture a specific tool type characterized the production of bifacial tools in the southern Levant. Although primarily made of flint (e.g., Barkai 2005), some were produced on basaltic rocks, limestone, and other more 'exotic' raw materials (e.g., Garfinkel \& Dag 2006; Rosenberg et al. 2008; Rosenberg \& Gopher 2010; Rosenberg 2011; Gluhak \& Rosenberg 2013; Rosenberg and Gluhak 2015; Vardi 2015).

Axes and adzes have long been identified as instruments used by ethnographic horticulturist and Neolithic societies for altering their environments and as a means of symbolic expression, specifically pertaining to men (e.g., Campbell-Smith 1965; Burton 1984; Claris \& Quartermaine 1989; Darvill 1989; Bradley \& Edmonds 1993: 53; Pétrequin \& Pétrequin 1993: 359-361; Thomas \& Tilley 1993; Cooney 1998; le Roux 1998; Pétrequin et al. 1998). These tools first appear in the southern Levant during the PPNA period (ca. 11,50010,500 Cal BP) and were manufactured and used until the end of Chalcolithic Period, ca. 3,900 Cal BP (e.g., Barkai 2011). The rare cases of bifacial tools that were made of materials other than flint, and specifically miniature bifacials, were often argued in the Levant to be "votive" or to bear a greater symbolic content than the more common flint bifacials (e.g., Rosen 1997:97; Barkai 2005:39-40). In the case of the PPNA, this was systematically examined and it was demonstrated that the ground stone bifacials mostly lacked use-wear, while the flint bifacials were heavily used and re-sharpened (Yerkes et al. 2003; Barkai 2005: 369).

\section{Giv'at Kipod}

Giv'at Kipod is located on the Manasseh Hills, Israel, ca. $20 \mathrm{~km}$ east of the Mediterranean Sea shoreline (Figure 1). The site has been explored since 2005 and both surveys and excavations revealed that it was a major extraction site for the production of bifacial tools (Shimelmitz et al. 2005; Rosenberg et al. 2008). The hill is one of several isolated igneous rock hills found along the southwestern margins of the Jezreel Valley. The lower outskirt of the hill is used for agriculture today and the remains of a small RomanByzantine fortress are found on the summit (Raban 1999: 60). The activities, in late antiquity and in modern times, clearly damaged the quarry site and concealed much of the prehistoric remains.

The slopes of the Giv'at Kipod hill are covered with knapped basanite items (Figure 2). Specifically, the southern and southeastern slopes are the richest in terms of accumulations of knapped material, and apparently less affected by later activities. These accumulations consist of hundreds of thousands of flaked basanite debitage and numerous rejected rough-outs. A close look at these massive concentrations of knapped material reveals that, apart from basanite, items made of other materials are extremely rare, and none can be ascribed to the Neolithic-Chalcolithic periods.

The largest of these accumulations, a massive pile of production waste (ca. $50 \mathrm{~m}$ long, 15 $\mathrm{m}$ wide and ca. $1.0 \mathrm{~m}$ thick), was selected for excavation and marked as Locus 1 (Figure 3). The surface of the pile is packed with thousands of production waste items, consisting of fragments, flakes, and bifacial rough-outs. During the excavations, a probe, $1 \mathrm{~m}$ wide and 10 $\mathrm{m}$ long, was marked, running along the pile's south-north axis. Six $\mathrm{m}^{2}$ within it were excavated (I1, I2, I5, I7, I8, I9, Figure 4). Each square in the grid was treated as an independent spatial unit and excavated in $10 \mathrm{~cm}$ spits. Sediments were sieved through a 2.4 $\mathrm{cm}$ screen. During the field work we separated the chunks and chips from the rest of the assemblage for counting and weighing. All rough-outs and waste items bearing a bulb of percussion were registered and taken for further analysis. 


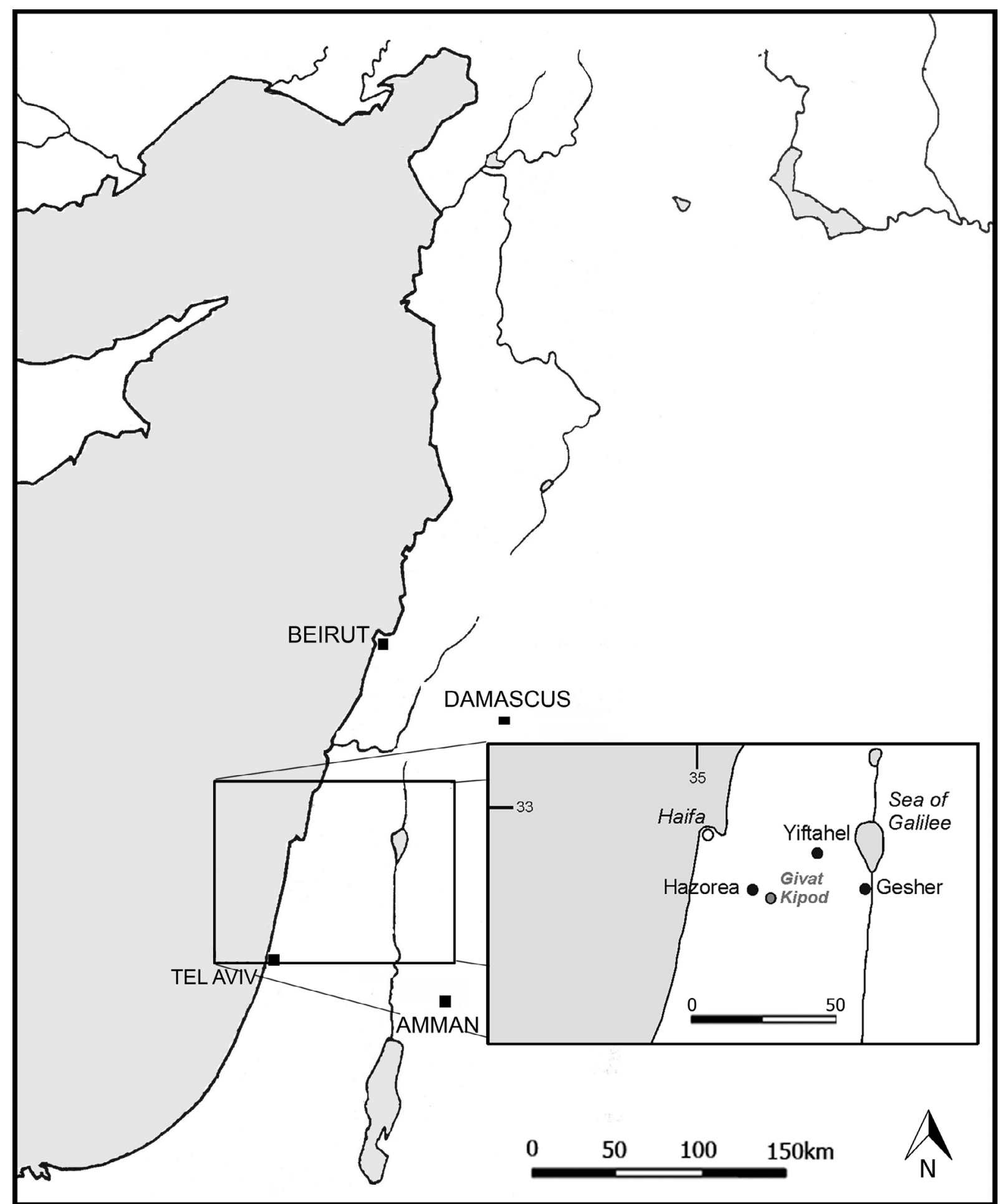

Figure 1. A map showing the location of Giv'at Kipod.

During excavations it became clear that the accumulation of basanite items in Locus 1 is dense and spread from surface to bedrock in the centre of the pile. The areas near the main pile now covered by basaltic sediments are in fact also rich with production debris, suggesting that the scale of production at the site was much more intensive than we can observe today. The centre of the pile reflects the densest accumulation (Figure 5). For example, the excavated volume of Square I5, a single cubic meter, yielded 9,320 knapped items with a total weight of $956 \mathrm{Kg}$ (reflecting the high density of knapped rock compared to soil). 


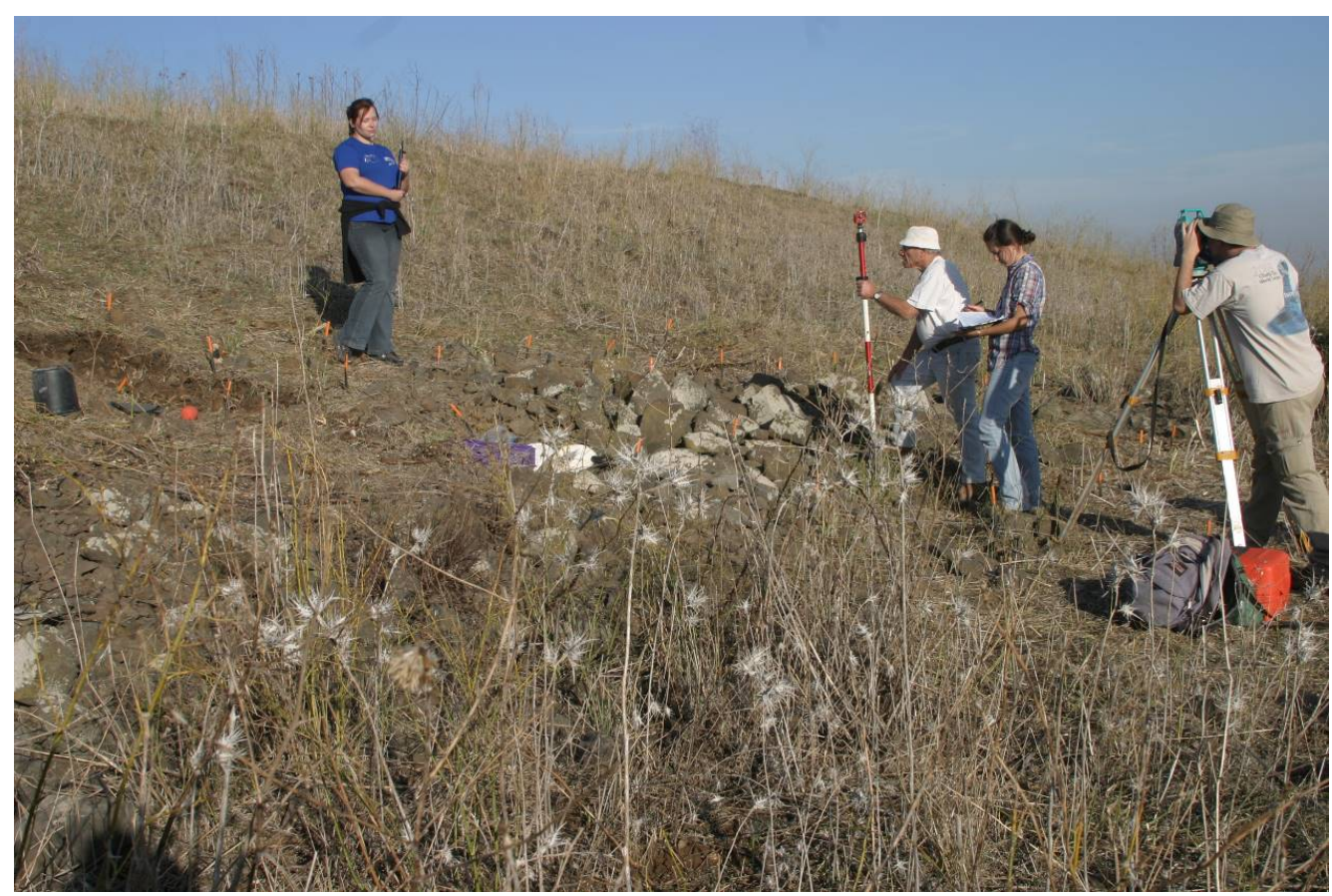

Figure 2. A view over the southern slope of the site.

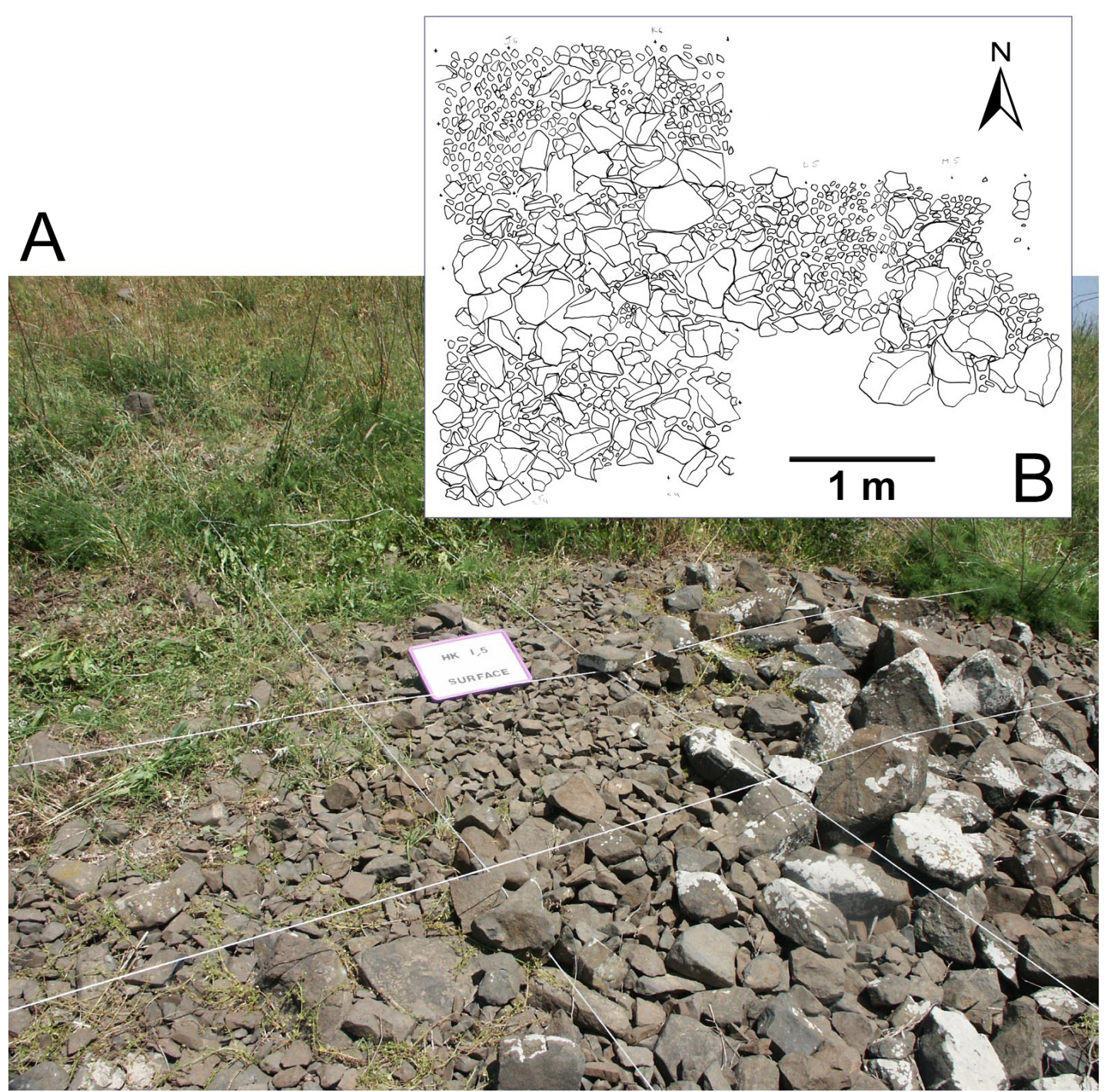

Figure 3. The centre of Locus 1 prior to excavation and a drawing of parts of its surface. 


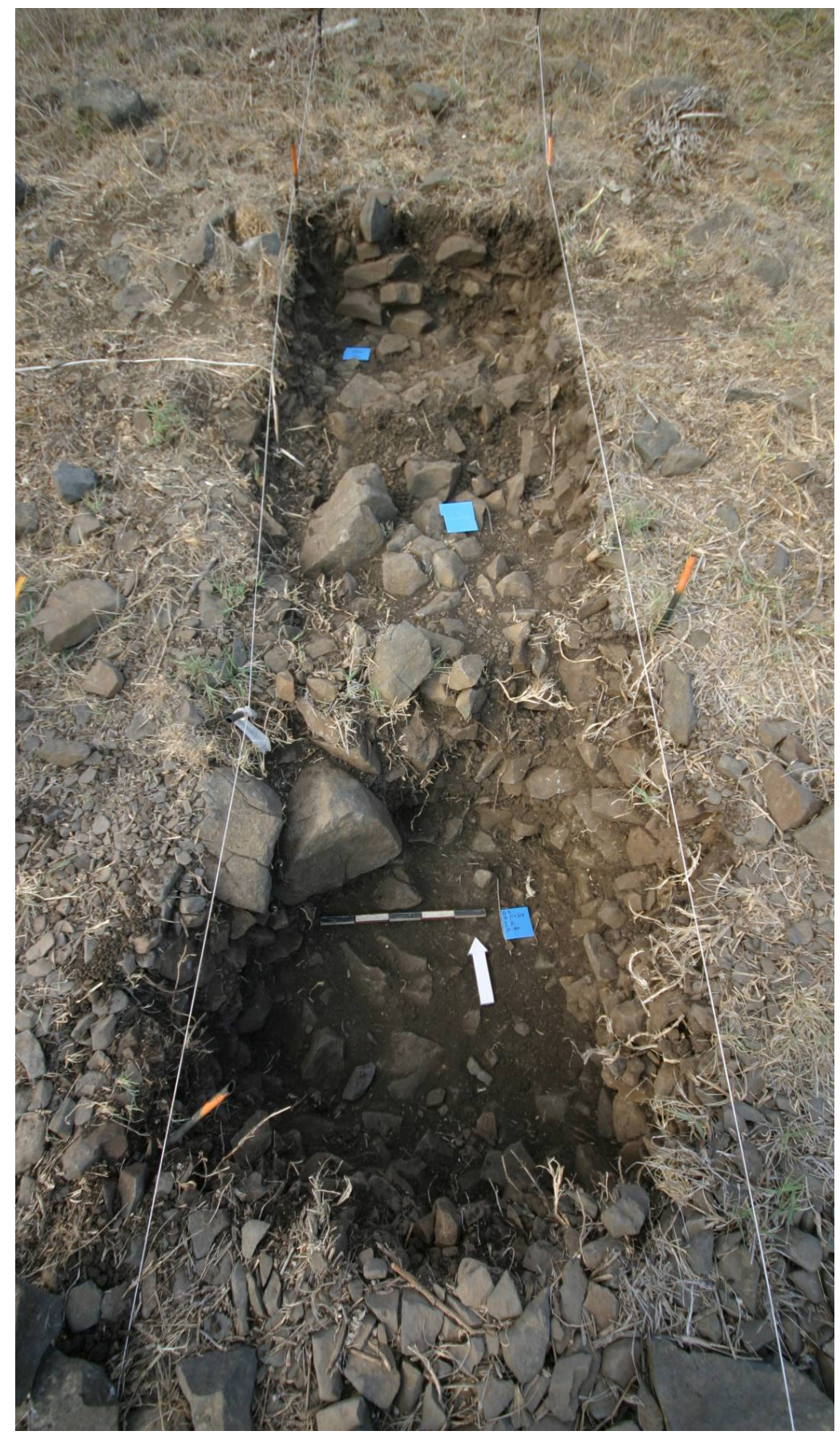

Figure 4. Squares. I7-I9 in Locus 1 during the 2007 excavation.

Two stratigraphic layers were distinguished at the centre of Locus 1: the lower is characterized by basanite items embedded in black-red soil, with a thickness of ca. $20-40 \mathrm{~cm}$ and the upper is characterized by accumulation of items with almost no sediment at all (Figure 6). Because the accumulation of sediment is later than the deposition of the waste the differentiation between the two layers noted above is apparently of little significance in terms of the original deposition of the lithic items. We have no clear information concerning the quarrying activity itself, as we reached the bedrock only in a small area in square I5. However, based on the accumulated data form the topography of the pile and the presence of large boulders (some $30-50 \mathrm{~cm}$ across), we can suggest that large boulders were quarried out, modified and reduced first into large flakes and then into preforms on site, and that the knappers discarded the production debris downhill. 


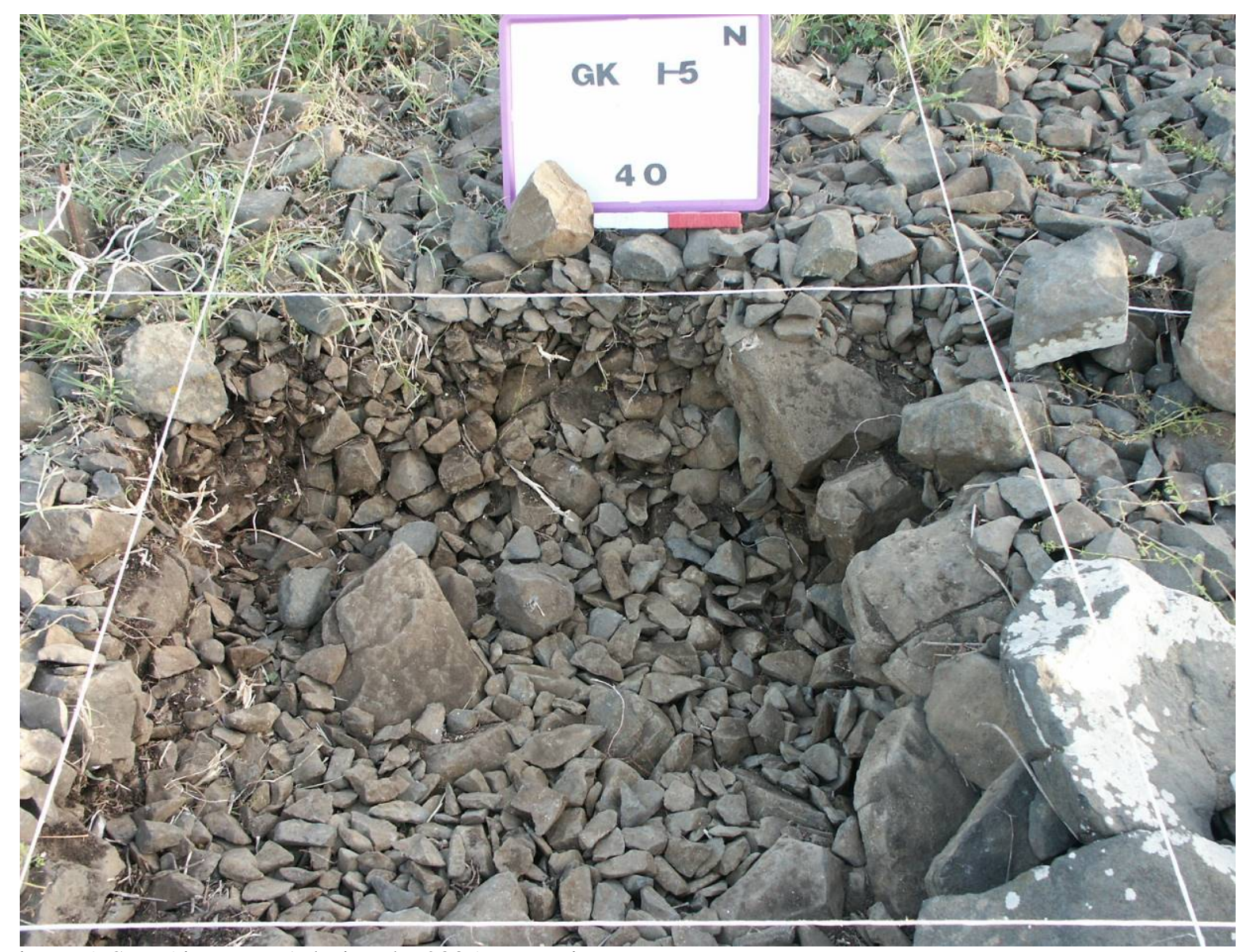

Figure 5. Sq. I5 in Locus 1 during the 2005 excavation.

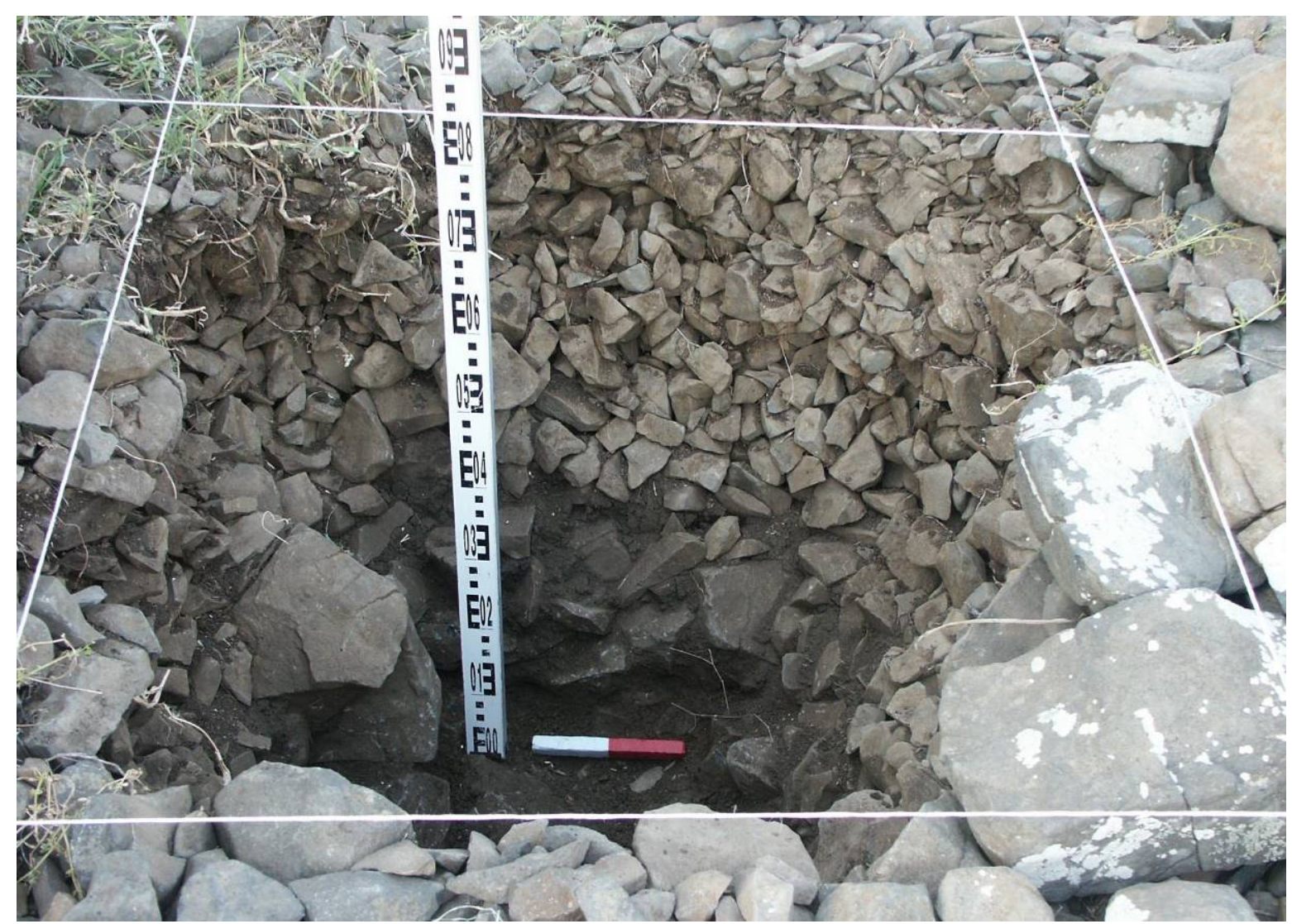

Figure 6. Square I5 showing the lower part packed with sediments. 
No indications of other Neolithic-Chalcolithic activities were found during the survey and excavation. In fact, the only non-basanite items found are some Roman-Byzantine pottery sherds and a few glass fragments, originated probably from the fortress atop of the hill. Small limestone chunks as well as highly decalcified, miniature flint pieces and a few flint chips that are not heavily patinated were found as well. The heavily eroded and decalcified flint items are similar to Palaeolithic material in the region (e.g., Olami 1984). The only reliable information concerning the dating of the Giv'at Kipod quarry and production site is based on the provenance study (Gluhak \& Rosenberg 2013), which identified bifacials made of Giv'at Kipod basanite in a series of sites spanning from the PPNA to the Late Neolithic-Early Chalcolithic period.

\section{The assemblage of Giv'at Kipod (Locus 1)}

\subsection{The waste}

From the six square meters excavated in Locus 1, ca. 150,000 basanite items were retrieved, weighting more than two tons (Table 1). The majority of the material, both in numbers and weight, are chunks and chips $(<1.5 \mathrm{~cm})$. The chunks are predominantly broken, knapped material (non-proximal flake fragments) and various other basanite pieces. This is indicated by the frequent presence of fragments bearing a ventral surface and scars of previous removals along their dorsal face. Items that are smaller than $1.5 \mathrm{~cm}$ but still bear a bulb of percussion were labelled as micro-flakes. Other kinds of production waste, including mainly flakes $(n=4,366)$, but also rejected rough-outs $(n=116)$ constitute only $285 \mathrm{~kg}$ (ca. 3\% in reference to number and ca.12\% in reference to weight).

Within the waste we recorded flakes bearing weathered dorsal surfaces which constitute a remnant of the original quarried block of raw material (pre-knapping) as primary elements (bearing at least $30 \%$ of the dorsal surface). A process of "decortication" of basanite was noted in other cases (e.g., Ishimura \& Addison 2007). Nevertheless, such flakes are few within the assemblage of Locus 1 (2.5\%). Flakes are the most common waste artefact found at Giv'at Kipod, constituting $86.9 \%$ of the debitage and rough-outs numerically and ca. $50 \%$ in weight. The majority of the flakes are characterized by plain platforms. Flakes with different types of modified platforms were recorded separately and are notably less common, constituting only $5.6 \%$ of the debitage and rough-outs in numbers and even less in weight. Blades are rare and as none of these demonstrate fine parallel edges or a homogenous crosssection, we believe these are incidental by-products of the bifacial production sequence.

Only one core was retrieved from the excavated volume, while several other 'giant cores' were observed on the surface of Locus 1 (their full description cannot be provided since they are embedded within the pile of Locus 1 in places not excavated yet) (Figure 7). Items bearing remnants of a striking platform from directions other than that they were knapped from were defined as core trimming elements. Although some of these were removed from boulders that were used as cores, most were probably reduced during the manufacturing process of bifacial tools. These appear in a variety of sizes and shapes, probably more common to earlier stages of the rough-out production in which large removals were made. In our preliminary analysis (Rosenberg et al. 2008) we mentioned the presence of several retouched items. However, following further study, we now suspect that these "retouched" edges represent, in fact, edge damage, resulting from contact between the basanite items within the pile, especially in places where soft sediments are lacking. 
Table 1: The basanite assemblage of Locus $1 .{ }^{*} 1,154$ chunks from the 2007 season were not weighed; their weight was estimated according to the rest of the chunks recorded; **the number of chips is estimated according to series of samples counted and weighed from different squares and spits, including a total of 28,653 chips.

\begin{tabular}{lcccccc}
\hline & $\mathbf{n}$ & $\begin{array}{c}\text { Weight } \\
\text { (kg) }\end{array}$ & $\begin{array}{c}\text { \% out of debitage and } \\
\text { rough-outs } \\
\text { (n) }\end{array}$ & $\begin{array}{c}\text { \% out of all } \\
\text { (weight) }\end{array}$ & $\begin{array}{c}\text { assemblage } \\
\text { (n) }\end{array}$ & (weight) \\
\hline Primary element & 126 & 15.21 & 2.5 & 5.3 & 0.1 & 0.7 \\
Flake & 4,366 & 147.34 & 86.9 & 51.7 & 2.8 & 6.3 \\
Modified base flake & 279 & 13.09 & 5.6 & 4.6 & 0.2 & 0.6 \\
Blade & 30 & 1.60 & 0.6 & 0.6 & 0.0 & 0.1 \\
Core trimming element & 42 & 8.02 & 0.8 & 2.8 & 0.0 & 0.3 \\
Core & 1 & 5.20 & 0.0 & 1.8 & 0.0 & 0.2 \\
Edge damage/ "retouched" item & 64 & 9.26 & 1.3 & 3.2 & 0.0 & 0.4 \\
Rough-out & 116 & 85.54 & 2.3 & 30.0 & 0.1 & 3.7 \\
Sum debitage and rough-out & 5,024 & 285.26 & 100 & 100 & & \\
Debitage and rough-out & 5,024 & 285.26 & & & 3.2 & 12.2 \\
Chunk* & 36,203 & 2004.18 & & & 23.1 & 85.9 \\
Chip** & 115,000 & 42.28 & & & 73.2 & 1.8 \\
Micro-flake & 818 & 0.11 & & & 0.5 & 0.0 \\
\hline Total & $\mathbf{1 5 7 , 0 4 5}$ & $\mathbf{2 3 3 1 . 8 2}$ & & & $\mathbf{1 0 0}$ & $\mathbf{1 0 0}$ \\
\hline
\end{tabular}

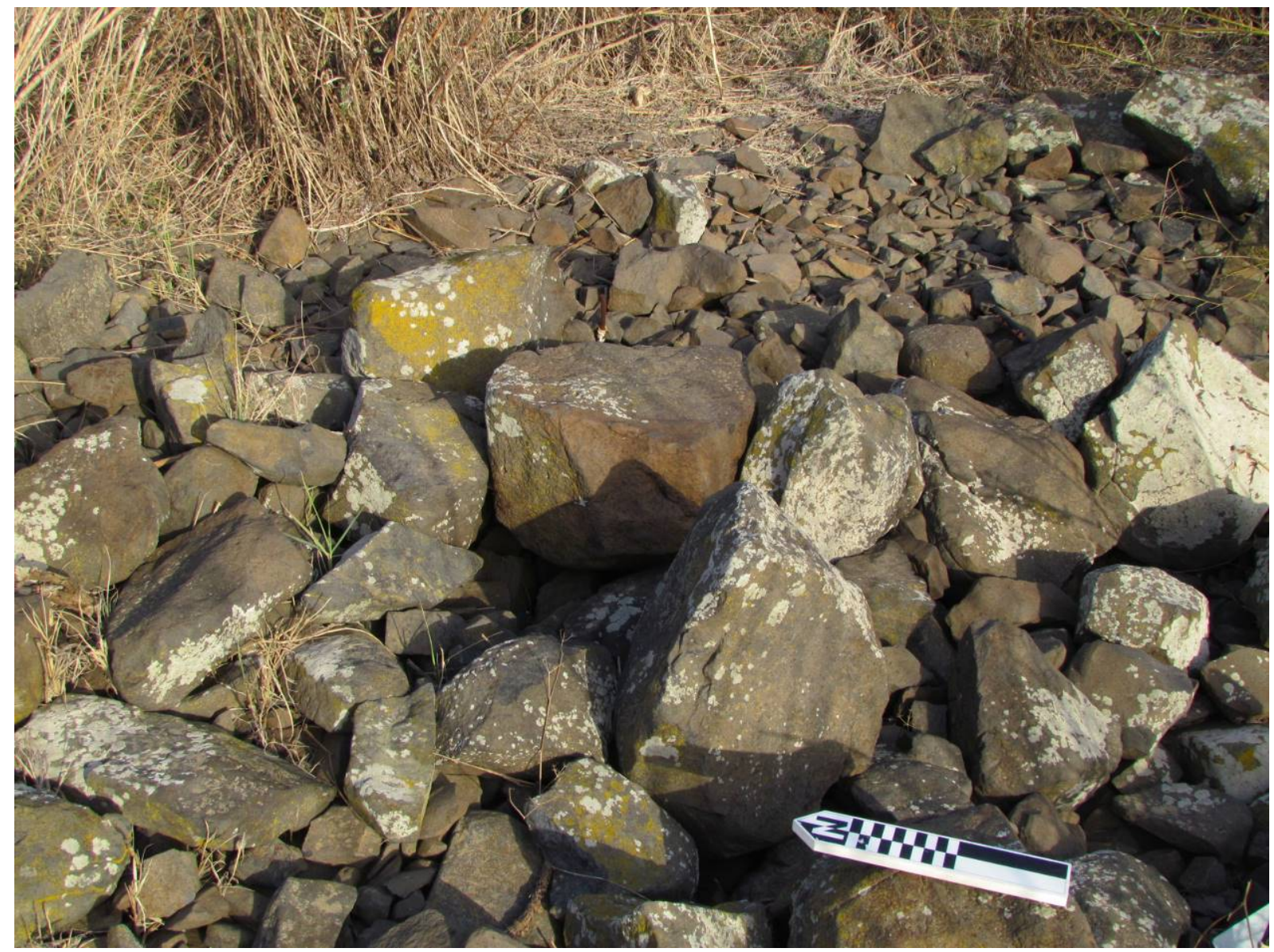

Figure 7. Large boulders, 'giant cores' and other waste material on the surface of Locus 1. 


\subsection{The rough-outs}

Rough-outs (Figures 8 and 9) consist of 116 items from the excavated material, while many more were found on the surface near Locus 1 and other parts of the hill. On average they weigh $0.737 \mathrm{~kg}$ (s.d. 0.62), although variations are considerable and the heaviest item measures $3.5 \mathrm{~kg}$.
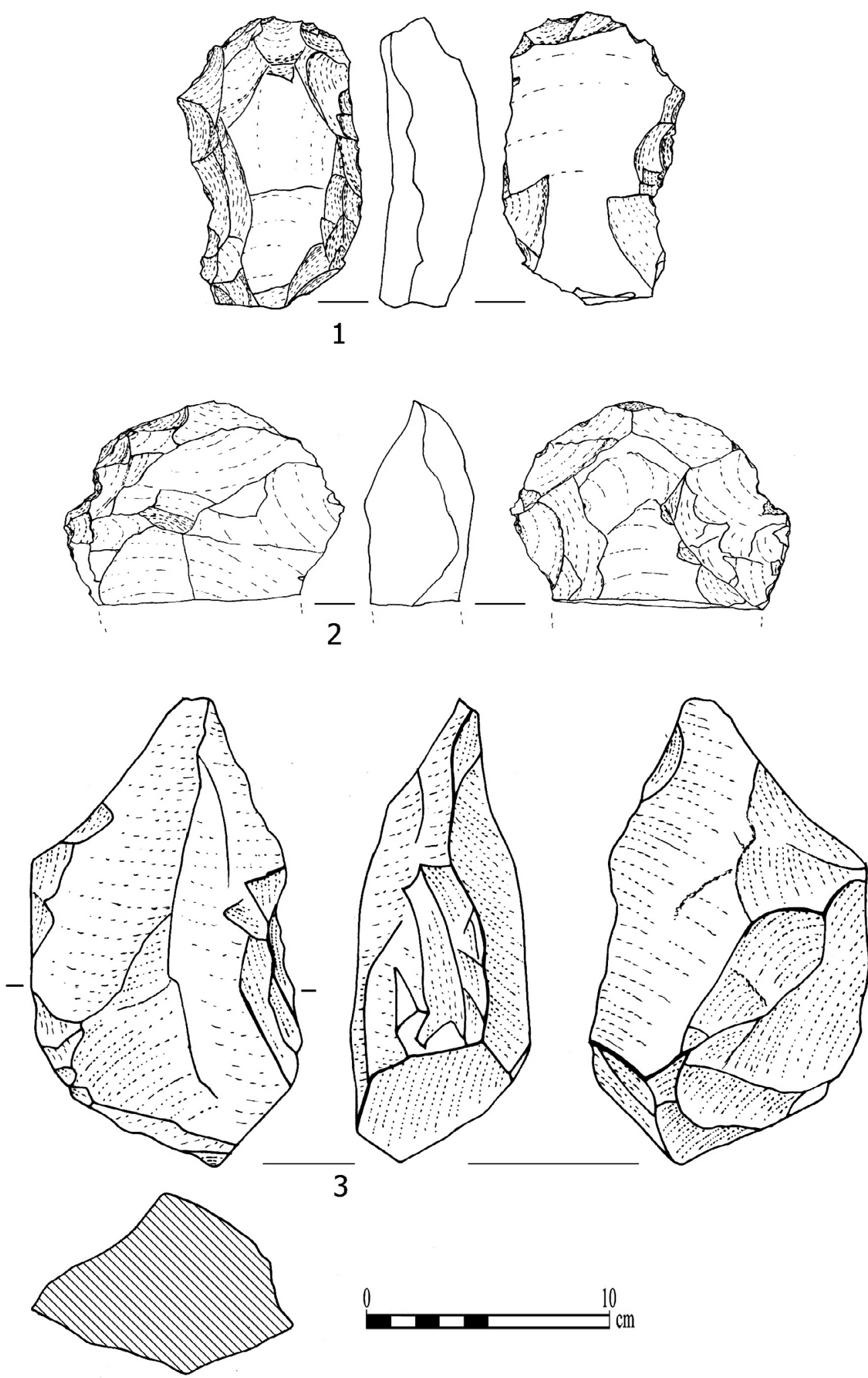

3

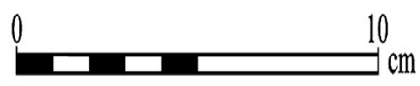

Figure 8. Basanite rough-outs from Locus 1. 

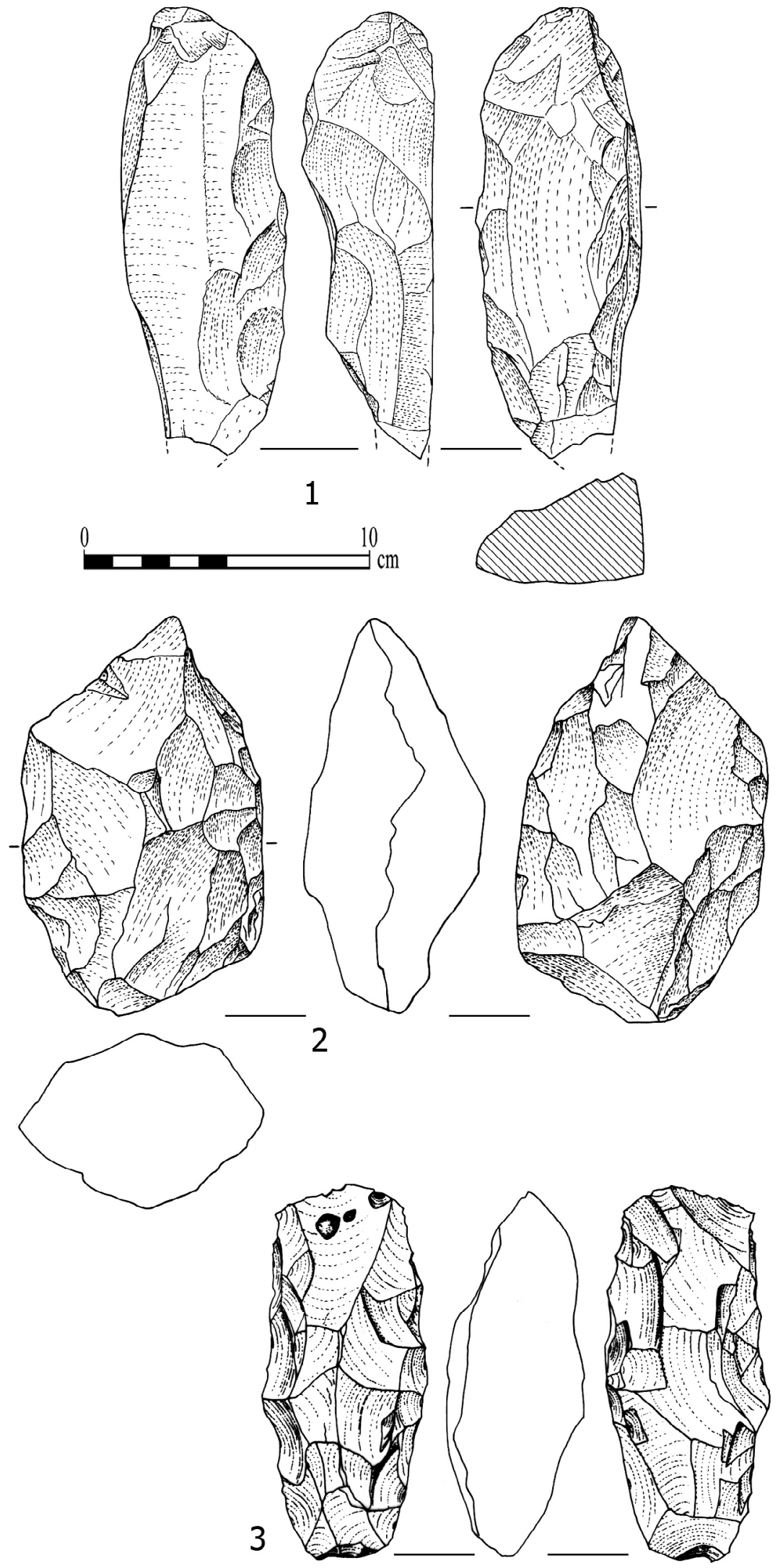

Figure 9. Basanite rough-outs from Locus 1.

We divided the rough-outs into three categories (Figure 10), tentatively representing different production stages, ranging from 'Stage I' rough-outs that include large fragments or flakes bearing only a few flaking scars, through 'Stage III' rough-outs, a category including all 
nearly finished items or bifacial rough-outs in which shape was apparently almost complete. These items usually bear the shapes of a well-defined bifacial tool, frequently an axe characterized by a lenticular cross-section. However, most rough-outs in the assemblage were defined as belonging to 'Stage II'. These include items in which a clear, designated shape is apparent or bearing circumferential or any other advanced bifacial flaking that covers at least three-quarters of the item's surface.

\section{Detachment of large flakes from "giant cores"}

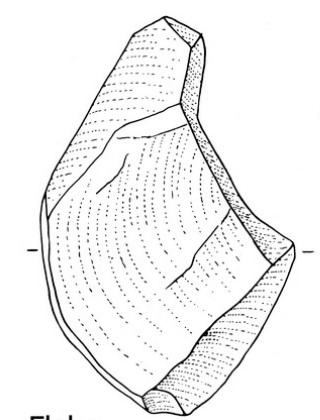

Flake
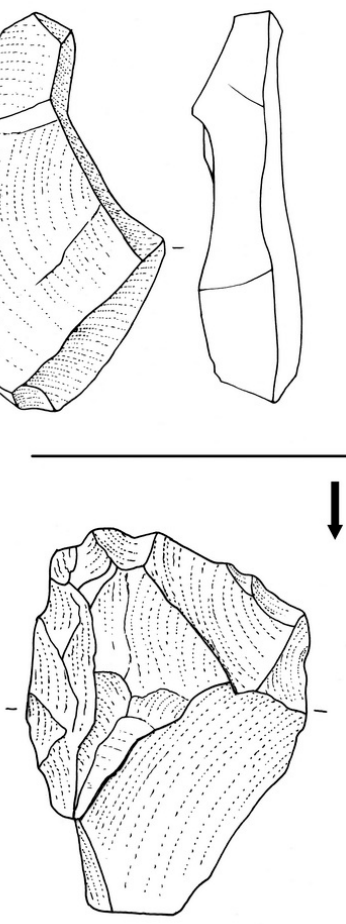

\section{Exploitation of naturally detached slabs}

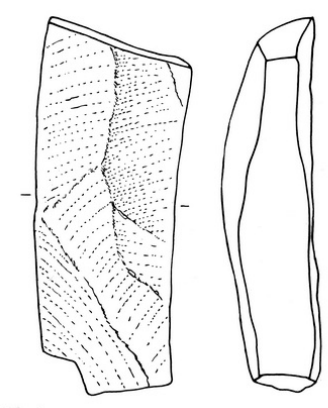

Slab

Character:

Large fragments or

flakes bearing only a

few flaking-scars

Stage 1

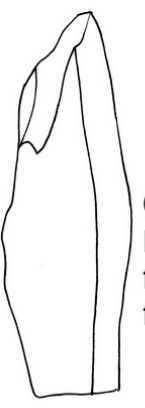

flaking-scars

Character:

Items with evidence of knapping

that cover at least three-quarters of the item's periphery

$\downarrow$

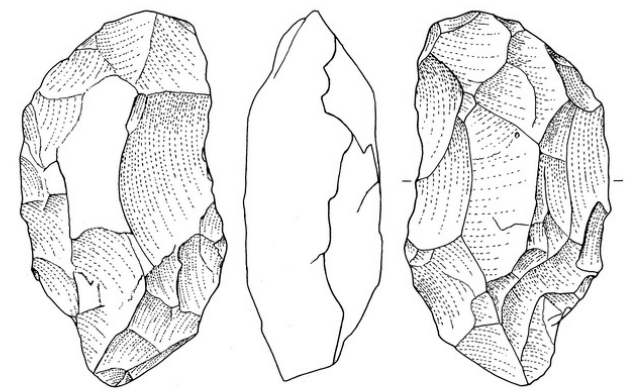

Stage 2

Stage 3

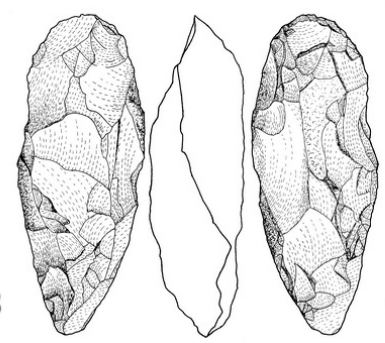

Character:

Bifacial roughouts with nearly complete shaping, usually exhibiting the shape of an axe

Figure 10. Stages of bifacial manufacture at the site. 


\section{Reconstructing Giv'at Kipod basanite bifacial reduction sequence}

While a few 'giant cores' were observed on the site's surface, only one large core was found within the excavated volume. The virtual absence of 'formal cores' used for regular blank removal indicates that the entire assemblage of Giv'at Kipod reflects the manufacture of bifacial tools, and that the retrieved debitage and debris are the waste of making these coretools. Also, the paucity of primary elements (defined by weathered surfaces predating the knapping of the item) indicates that an effort was made to extract basanite of pristine condition most suitable for knapping.

Although the methods of quarrying remain unknown, since we lack extraction surfaces, there is reason to assume that basanite slabs and boulders were easily accessible. This is suggested by the hill's northern slope, where a modern aggregate quarry is present, revealing the fragmentation of the basanite bedrock close to the current surface into both slabs and boulders. The basanite slabs often have shapes fairly close to those of bifacial rough-outs, and it is probable that a single slab would have been modified to produce a single bifacial tool. Boulders occur in various sizes; and some of the 'giant cores' documented on the surface of Locus 1 clearly reflect boulders that were subjected to some amount of modification prior to their discard. Scars, visible on their surface, indicate the production of large flakes that could have served as blanks for shaping bifacial tools. Without refitting we could only draw general differences between the extent of using slabs or boulders, in which the paucity of cores suggests that bifacial tools were primarily made on slabs.

In general, the flakes removed during bifacial knapping vary according to the stage of manufacture. Earlier stages involve the removal of relatively rough flakes, while during later stages thin flakes, often with multi scar patterns, are produced, usually described as thinning flakes (e.g., Andrefsky 2005: 123-124). The number of flakes with modified (faceted) platforms is expected to increase with the progression of the reduction sequence, since the latter would be detached from a well-defined bifacial ridge. While the use of basanite might cause a bias towards thicker flakes, the paucity of clear thinning flakes might also be affected by the nature of the raw material in which delicate thin blanks often broke after knapping. In fact, among the chunks and chips, flat basanite fragments that may be broken thinning flakes are common.

Discard was apparently affected by various factors, including preform breakage, which is well-represented. The few items ascribed to 'stage III' usually have an elongated shape and lenticular section, indicating that the production was primarily focused on axes.

No features relating to the polishing of the bifacials such as grooved marks on stone surfaces were noted at the site or its vicinity. This, together with the fact that smoothed and polished bifacials commonly recovered from Neolithic settlements (e.g., Dorrell 1983; Samzun 1994; Gopher 1997; Garfinkel \& Dag 2006; Rosenberg \& Gopher 2010; Rosenberg 2011; in press) were not identified, suggests that the final stages of the bifacial tool production were carried out elsewhere, possibly at habitation sites, as known from the ethnographic record (e.g., Pétrequin \& Pétrequin 1993; Barkai 2005: 176).

\section{Discussion}

In the Levant, bifacials made on non-flint raw materials (including basanite), were often entirely or partly polished, which together with their specific selection of raw material suggests greater symbolic content compared with flint bifacials (Rosen 1997: 93-97). Polish is certainly found on many of the south Levantine flint bifacials as well, but is typically limited to the active edge (Barkai 2005). Furthermore, while use-wear is common on flint bifacials, it is reported to be missing or rare on bifacials made of other raw materials (Yerkes et al. 2003). 
The specific characteristics of raw material procurement vary across societies, but based on earlier studies, we suggest that it can be grouped into three general modes:

1. Raw material procurement is an undifferentiated component of general patterns of resource exploitation throughout the landscape. This mode is often embedded within a larger framework of mobility patterns (e.g., Binford 1979; Brantingham 2003).

2. Raw material procurement is part of a specialized production where the knappers occupy the sources for relatively long time spans. This pattern is more common among agricultural and urban societies, in which trade or exchange constitute important economic vehicles (e.g., Costin 1991; Rosen 1997; Shimelmitz 2009; Barzilai 2011; Ebeling \& Rosenberg 2016).

3. Raw material locality is perceived as a highly special point in the landscape and visiting these localities is treated as the focus of the event (e.g., Gould \& Saggers 1985; Ross et al. 2003; Brumm 2010).

While the two former modes are reflected in numerous archaeological studies, the latter mode is less familiar in archaeological contexts. We argue that the site of Giv'at Kipod represents this third mode of raw material procurement and demonstrate it through several aspects pertaining to the site and its particular characteristics:

\subsection{The uniqueness of Giv'at Kipod in terms of the extraction of basanite for the making of bifacials}

Currently, Giv'at Kipod is the only known quarry and production site for basaltic bifacial tools in the southern Levant, although a recent geochemical study showed that other locals also served this purpose (Gluhak \& Rosenberg 2013; Rosenberg and Gluhak 2015). Similar sites, exploiting non-flint resources, are also rare and include three larnite quarry and bifacial production sites in the Negev of Israel (Vardi 2015), and others, much northern sites in Turkey, Thrace (e.g., Özbek 2000, Özbek \& Erol 2001). On the other hand, quarry and production sites with flint bifacial manufacture are common in the southern Levant (e.g., Ronen and Davis 1970; Barkai 2005; Schyle 2007; Shimelmitz \& Mendel 2008; Rosenberg et al. 2009).

\subsection{Giv'at Kipod as a production centre for basanite bifacials}

The large amount of rough-outs at Giv'at Kipod and the relative paucity of basanite bifacial tools in the Levantine sites (Rosenberg et al. 2008), implies that production at Giv'at Kipod was sufficient to produce bifacial tools for a large number of communities. Furthermore, a provenance study recently showed that the site operated for several millennia, from the PPNA through the period of the Wadi Rabah culture (Gluhak \& Rosenberg 2013). Nevertheless, the distribution range of Giv'at Kipod bifacials was limited (Rosenberg \& Gluhak 2015). This, in turn, suggests that the significance of producing basanite bifacials at Giv'at Kipod crossed chronological and cultural boundaries yet had a limited geographic impact. Throughout this time frame, basanite bifacials remained marginal in quantity in relation to bifacials made of flint, thus keeping their unique character within the assemblages of the southern Levant.

The waste found at the site indicates that the production focused on achieving only the general shape of the bifacial tools and that final shaping, by abrading and polishing was conducted elsewhere. The amount of production waste is extensive (e.g., our limited examination of ca. $2.5 \mathrm{~m}^{3}$ resulted in more than two tons of knapped basanite with 116 rejected rough-outs) and thus we assume that hundreds if not thousands of bifacials were made at the site. 


\subsection{The unique focus of production in Giv'at Kipod on a single product}

Our study of Giv'at Kipod demonstrates extensive exploitation of basanite, all of which was directed to the production of bifacial tools, mainly axes. This focus on the production of a single product, bifacials in this case, is a remarkable feature that distinguishes Giv'at Kipod from many other contemporary workshop sites.

Quarrying and knapping at raw material sources appear in the Levant already from the Lower Palaeolithic (e.g., Barkai et al. 2006; Barkai \& Gopher 2009; Ekshtain et al. 2012) and continue into historical periods (Shimelmitz et al. 2000; Rosen \& Schneider 2001; Rosenberg \& Nadel 2009; Rosenberg et al. 2011). Alongside production waste, other items are also found in these sites, indicating additional activities other than tool manufacture. Although the Palaeolithic workshop sites probably represent both the extraction of raw material in general and the making of a variety of tools that might aimed to be transported elsewhere, we find many non-formal tools such as denticulates, notches and retouched items which probably relate to expedient activities conducted on site (e.g., Barkai et al. 2006; Rosenberg et al. 2009; Nadel et al. 2011). In the case of the Neolithic, even in sites where the specialized production focused on the manufacture of a single type of items such as bifacials, a variety of tool types were found as well (e.g., Rosenberg et al. 2009).

The appearance of a variety of tools within most workshop sites is not surprising and in fact is even expected as reflecting the scheduling of raw material procurement within a larger set of activities performed within the landscape. This is precisely what makes Giv'at Kipod so special (although the recent larnite sites from the Negev may represent a similar phenomenon; Vardi 2015). Our volume of excavation is no different from that excavated at other workshop sites in Israel. Furthermore, in most cases the archaeological investigation is based only on survey or systematic collection (e.g., Barkai \& Gopher 2009; Rosenberg et al. 2009; Gopher \& Barkai 2011; Nadel et al. 2011). The tools in these workshops sites can appear in high frequencies although they are usually characterized as expedient or ad-hoc in character (Barkai \& Gopher 2009: 178; Gopher \& Barkai 2011: 218).

\subsection{Does Giv'at Kipod reflect craft specialization?}

The role of craft specialization in the formation of complex societies has long been debated (e.g., Costin 1991; Schortman \& Urban 2004; Vaughn 2006) and the increased specializations in the Levant during the Neolithic period were the subject of several studies in the last two decades (e.g., Quintero \& Wilke 1995; Barzilai 2011). It is thus of importance to examine whether the manufacture of bifacials at Giv'at Kipod was part of this development or whether it is the result of a different mode of behaviour. Various definitions were offered for craft specialization, most of which relate to societies with a more complex structure than that of the Levantine Neolithic. Although the presence of part time specialization is well acknowledged, the focus is on the more permanent and institutionalized cases (e.g., Brumfiel \& Earle 1987; Clark \& Parry 1990; Costin 1991).

We prefer to follow the definition used by Cross (1993:65) in his study of non-stratified societies where he defined specialization “... as a situation in which a relatively large portion of the total production of a given item or class of items is generated by a small segment of the population". Costin (1991) offered various characteristics for examining the presence and character of specialization. In reference to our particular context, our assumption is that if the production was specialized two elements should appear: standardization and an inclusion of waste of "domestic" character within the site. Standardization is expected to appear due to the routine manufacture of the specialists, their high familiarity with the raw material they work with (its advantages and pitfalls) and by gaining high level of skill from their repeated work (Costin 1991). Typical "domestic” waste is expected to appear in early specialization contexts 
as this was usually engaged within the domestic sphere or its activities (e.g., Hartenberger et al. 2000).

Although standardization is usually examined through the characteristics of the endproducts, which are altogether missing from the site, it can also be appreciated through an observation of the rejected items and debitage. In many of the bifacial workshops of the southern Levant, rejects representing production failures in a relatively advanced stage of production (comparable to our Stage III) exhibiting a clear shape of a bifacial tool with lenticular section are common (e.g., Schyle 2007; Shimelmitz \& Mendel 2008). At Giv'at Kipod on the other hand, rough-outs that approach the final products are few and most were discarded during relatively early phase of their production. These are highly variable in characteristics and do not show the exceptional skill expected of craft specialists.

The waste accumulation of lithic workshops from the Levant is usually characterized by a variety of additional materials, including not only a range of tool types but also general "domestic" waste such as bones, ceramics, broken ground stone implements etc. (e.g., Gilead et al. 2004). None of these were found however at Giv'at Kipod. The lack of any evidence for domestic activity or standardization underscores the interpretation that Giv'at Kipod was not used by a small group of specialized knappers that lived at, or frequently visited the site.

\subsection{Towards an 'Alyawara day' model of raw material extraction}

Our study clearly indicates that Giv'at Kipod was a quarry and production centre that specifically served for the manufacture of basanite bifacials over a period of several millennia, in the course of which its products were distributed to several sites in the region. At present, no mechanism of specialized production was identified at the site. The rarity of other finds suggests that the site was perceived as a special location in the landscape - one that is used exclusively for the production of specific artefact type from a specific type of rock. This is mirrored in some anthropological reports as well, which dealt with raw material extraction (e.g., Gould \& Saggers 1985; Ross et al. 2003; Brumm 2010). For example, Gould \& Saggers (1985) described specific trips for the procurement of raw material which were made by men only. These trips were not made to obtain raw material in general, but rather a specific type of raw material. Gould \& Saggers (1985: 122) stated that “...all male groups making such trips, often over hundreds of kilometres from their home areas, to introduce novices to sacred landmarks and the myths associated with them”. In Papua, New Guinea, before going to the quarry a fast was conducted that lasted for part of the quarrying time as well (Rhoads \& Mackenzie 1991). These behavioural patterns are in complete difference to the regular everyday raw material procurement. For instance, Binford (1979: 259) in his study of the Nunamiut argued that "raw materials used in the manufacture of implements are normally obtained incidentally to the execution of basic subsistence tasks".

It seems these two sets of behaviours can be seen in the procurement of flint in general versus the procurement of basanite in Giv'at Kipod. While the former according to the record of the Levant was commonly conducted not as an exclusive single task but rather as a task comingled with other sets of tasks, the latter lack any other evidence of other task engaged with it. While the anthropological record is rich with cases describing the rituals and habits relating to the visit and use of raw material sources (e.g., Binford \& O'Connell 1984; Pétrequin et al. 1998), by most current archaeological means, most would be hard to track.

The unique case of Giv'at Kipod, as described here, seems to provide a novel perspective for the possibility of observing this type of behaviour in the archaeological record. Following the seminal study of Binford \& O'Connell (1984), we suggest that this type of quarry and production site, demonstrating a very limited set of activities relating to a specific raw material and tool type with the almost absence of waste of any other activity, indicates a 
unique social context in which knapping occurred. For this type of organization of production we suggest the framework of Alyawara day model of raw material extraction. We are fully aware that in their paper "An Alyawara Day: The stone quarry”, Binford \& O'Connell (1984) described a journey to the quarry which was set by the elders and only mimics the "old ways" of life. As such, it is not representative of an original set of events as normally occurred before modern colonization of Australia. Nevertheless, as many others, we find this work of prime importance in the study of quarry and raw material exploitation and thus selectively choose to use it as a title for the suggested model, despite the obvious difficulties steaming from the analogy.

We thus suggest that such a model which can aid in identifying similar sites should be based on the five themes explored above in the case of Giv'at Kipod (these however are just general lines that must be further perused by adding more examples of this type of behaviour):

1) The site consists of a raw material that constitutes a unique choice among a variety of available alternatives; the special importance of the raw material will be witnessed in the characteristics and life-history of the end-products.

2) The end-products of the quarry sites should not be found just in a single site, but should be found in a number of sites.

3) The manufacturing process is geared towards a very particular type of end-product(s), in contrast to other outcrops where a large variety of tools were made.

4) No other activity other than the manufacture of the designated end-products should be evidenced at the site.

5) The activity does not reflect craft specialization, but fits the character of waste produced by a notable number of individuals visiting the site.

Giv'at Kipod, a rare occurrence in the Levantine archaeological landscape, provides a valuable and uncommon addition to our understanding of Neolithic-Chalcolithic modes of production and a venue to pursue new directions in the study of raw material procurement strategies. We demonstrated that its different character is revealed when compared with the archaeological record from other quarry and workshop sites throughout the Levant. Interestingly, this very particular mode of behaviour at the outcrop of Giv'at Kipod seems to have lasted for millennia, a point that further supports the notion that the site and its products had an exceptional cultural significance in the late prehistory of the southern Levant.

\section{Acknowledgments}

Excavations at Giv'at Kipod were supported by the Irene Levi Sala Care Archaeological Foundation and the Zinman Institute of Archaeology. We are thankful to A. Regev-Gisis for her help with the graphics. Ron Shimelmitz would also like to thank the W. F. Albright Institute of Archaeological Research for their support through the Barton Award. We also thank Assaf Nativ and O. Özbek for his helpful comments.

\section{References}

Andrefsky, W. 2005, Lithics: Macroscopic Approaches to Analysis. Cambridge University Press, Cambridge, 321 p.

Bar Yosef, O. 1991, Raw material exploitation in the Levantine Epi-Paleolithic. Raw Material Economies among Prehistoric Hunter-Gatherers (Monte-White, A., \& Holen, S., Eds.), Publications in Anthropology, Lawrence, p. 235-250. 
Bar-Yosef, O. 1994, The Lower Paleolithic of the Near East. Journal of World Prehistory, 8(3): 211-265. doi:10.1007/bf02221050

Bar-Yosef, O., \& Goren-Inbar, N. 1993, The Lithic Assemblages of 'Ubeidiya - A Lower Palaeolithic Site in the Jordan Valley. Qedem Vol. 34, The Hebrew University of Jerusalem, Jerusalem, 266 p.

Barkai, R. 2005, Flint and Stone Axes as Cultural Markers: Socio-Economic Changes as Reflected in Holocene Flint Tool Industries of the Southern Levant. Studies in Early Near Eastern Production, Subsistence and Environment Vol. 11, Ex Oriente, Berlin, 410 p.

Barkai. R. 2011, The evolution of Neolithic and Chalcolithic woodworking tools and the intensification of human production. Axes, adzes and chisels from the Southern Levant. In: Stone Axe Studies III (Davis, V., \& Edmonds, M., Eds.), Oxbow, Oxford: p. 39-54.

Barkai, R., \& Gopher, A. 2009, Changing the face of the earth: Human behavior at Sede Ilan, an extensive Lower-Middle Palaeolithic quarry site in Israel. In: Lithic Materials and Paleolithic Societies (Adams, B., \& Blades, B.S., Eds.), Wiley-Blackwell, Chichester: p. 174-185. doi:10.1002/9781444311976.ch12

Barkai, R., Gopher, A., \& La Porta, P.C. 2006, Middle Pleistocene landscape of extraction: Quarry and workshop complexes in Northern Israel. In: Axe Age: Acheulian Toolmaking - from Quarry to Discard (Goren-Inbar, N., \& Sharon, G., Eds,), Equinox Publishers, London: p. 7-44.

Barzilai, O. 2011, Social Complexity in the Southern Levantine PPNB as Reflected through Lithic Studies. BAR International Series Vol. 2180, Archaeopress, Oxford, 194 p.

Binford, L.R. 1979, Organization and formation processes: Looking at curated technologies. Journal of Anthropological Research, 35: 255-273. doi:10.1086/jar.35.3.3629902

Binford, L.R., \& O'Connell, J.F. 1984, An Alyawara day: The stone quarry. Journal of Anthropological Research, 40(3): 406-432. doi:10.1086/jar.40.3.3629763

Bradley, R., \& Edmonds, M. 1993, Interpreting the Axe Trade. Production and Exchange in Neolithic Britain. Cambridge University Press, Cambridge, 252 p.

Brantingham, P.J. 2003, A neutral model of stone raw material procurement. American Antiquity, 68(3): 487-509. doi:10.2307/3557105

Brumfiel, E.M., \& Earle, T.E. 1987, An introduction. In: Specialization, Exchange, and Complex Societies (Brumfiel, E.M., \& Earle, T.E., Eds.), Cambridge University Press, Cambridge: p. 2-9.

Brumm, A. 2010, "The falling sky”: Symbolic and cosmological associations of the Mt William Greenstone axe quarry, Central Victoria, Australia. Cambridge Archaeological Journal, 20(2): 179-196. doi:10.1017/s0959774310000223

Burton, J. 1984, Quarrying in a tribal society. World Archaeology, 16(2): 234-47. doi:10.1080/00438243.1984.9979930

Campbell-Smith, W. 1965, The distribution of jade axes in Europe with a supplement to the catalogue of those from the British Isles. Proceedings of the Prehistoric Society, 31: 2533. doi:10.1017/s0079497x00014699 
Cauvin, M.-C. 1998, L'obsidienne au Proche et Moyen Orient. In: L'Obsidienne au Proche et Moyen Orient (Cauvin, M.-C., Gourgaud, A., Gratuze, B., Arnaud, N., Poupeau, G., Poidevin, J.-L., \& Chataigner, C., Eds.), BAR International Series Vol. 738, Archaeopress, Oxford: p. 7-11. (in French) (“Obsidian in Middle East”)

Claris, P., \& Quartermaine, J. 1989, The Neolithic quarries and axe factory sites of Great Langdale and Scafell Pike: A new field survey. Proceeding of the Prehistoric Society, 55: 1-25. doi:10.1017/s0079497x00005326

Clark, J., \& Parry, W. 1990, Craft specialization and cultural complexity. Research in Economic Anthropology, 12: 289-346.

Cooney, G. 1998, Breaking stones, making places: The social landscape of axe production sites. In: Prehistoric Ritual and Religion (Gibson, A., \& Simpson, D., Eds.), Sutton Publishing, Stroud: p. 108-118.

Costin, C. 1991, Craft Specialization: Issues in defining, documenting, and explaining the organization of production. Archaeological Method and Theory, 3: 1-57.

Costin, C.L. 2005, Craft production. In: Handbook of Archaeological Methods (Herbert, D.G., Ed.), Maschner, AltaMira, Walnut Creek: p. 1032-1105.

Cross, J.R. 1993, Craft specialization in non-stratified societies. Research in Economic Anthropology, 14: 61-84.

Darvill, T. 1989, The circulation of Neolithic stone and flint axes: A case study from Wales and the Mid-West of England. Proceedings of the Prehistoric Society, 55: 27-43. doi:10.1017/s0079497x00005338

Delage, C. 2007, Chert availability in Israel and Palestine: A regional assessment based on data from the Galilee. In: Chert Availability and Prehistoric Exploitation in the Near East (Delage, C., Ed.), BAR International Series Vol. 1615, Archaeopress, Oxford: p. 29-53.

Dorrell, P.G. 1983, Appendix A - Stone vessels, tools and objects. In: Jericho V (Kenyon, K., \& Holland, T.A., Eds.), British School of Archaeology in Jerusalem, London: p. 485575.

Ebeling, J., \& Rosenberg, D. 2016, A basalt vessel workshop at Iron Age Hazor - Its context, products and implications. Journal of Field Archaeology, 40(6): 665-674. doi:10.1080/00934690.2015.1101941

Ekshtain, R., Brazilai, O., Inbar, M., Milvesky, I., \& Ullman, M. 2012, Givat Rabi East, a new Middle Paleolithic knapping site in the Lower Galilee (Israel). Paléorient, 37(2): 107122. doi:10.3406/paleo.2011.5426

Garfinkel, Y., \& Dag, D. 2006, Gesher: A Pre-Pottery Neolithic A site in the Central Jordan Valley, Israel. A final report. Ex Oriente, Berlin, 214 p.

Gilead, I., Marder, O., Khalaily, H., Fabian, P., Abadi, Y., \& Yisrael, Y. 2004, The Beit Eshel Chalcolithic flint workshop in Beer Sheva: A preliminary report. Journal of the Israel Prehistoric Society, 34: 245-263.

Gluhak, T.M., \& Hofmeister, W. 2009, Roman lava quarries in the Eifel region (Germany): Geochemical data for millstone provenance studies. Journal of Archaeological Science, 36(8): 1774-1782. doi:10.1016/j.jas.2009.04.007 
Gluhak, T.M., \& Rosenberg, D. 2013, Geochemical discrimination of basaltic sources as a tool for provenance analyses of bifacial tools in the southern Levant: First results from the Jezreel Valley, Israel. Journal of Archaeological Science, 40: 1611-1622. doi:10.1016/j.jas.2012.11.003

Gopher, A. 1989, The Flint Assemblages of Monhata. Association Paléorient, Paris, 162 p.

Gopher, A. 1997, Ground stone tools and other stone objects from Netiv Hagdud. In: An Early Neolithic Village in the Jordan Valley. Part 1: The Archaeology of Netiv Hagdud (Bar-Yosef, O., \& Gopher, A., Eds.), Peabody Museum of Archaeology and Ethnology, Harvard University, Cambridge: p. 151-176.

Gopher, A., \& Barkai. R. 2011, A new Neolithic quarry complex at Har Gevim, Israel: An introduction. In: Proceedings of the 2nd International Conference of the UISPP Commission on Flint Mining in Pre-and Proto-historic Times (Madrid, 1 4e17 October 2009), BAR International Series. Vol. 2260, Archaeopress, Oxford: p. 275-282.

Goren-Inbar, N. 2011, Culture and cognition in the Acheulian industry: A case study from Gesher Benot Ya'aqov. Philosophical Transactions of the Royal Society, 366: 10381049. doi:10.1098/rstb.2010.0365

Gould, R.A., \& Saggers, S. 1985, Lithic procurement in Central Australia: A closer look at Binford's idea of Embeddedness in archaeology. American Antiquity, 50(1): 117-136. doi:10.2307/280637

Hartenberger, B., Rosen, S., \& Matney, T. 2000, The Early Bronze Age blade workshop at Titris Höyük: Lithic specialization in an urban context. Near Eastern Archaeology, 63(1): 51-58. doi:10.2307/3210808

Hayden, B. 1987. Traditional metate manufacturing in Guatemala using chipped stone tools. In: Lithic Studies Among the Contemporary Highland Maya (Hayden, B., Ed.), University of Arizona Press, Tucson: p. 8-119.

Healey, E. 2001, The role of obsidian at the Halaf site of Domuztepe, s.e. Anatila. In: Beyond Tools (Caneva, I., Lemorini, C., Zampetti, D., \& Biagi, P., Eds.), Ex Oriente, Berlin: p. 389-397.

Hovers, E. 2001, Territorial behavior in the Middle Paleolithic of the Southern Levant. In: Settlement Dynamics of the Middle Paleolithic and Middle Stone Age (Conard. N.J., Ed.), Kerns Verlag, Tübingen: p. 123-152.

Ishimura, T., \& Addison, D.J. 2007, Ateliers of basalt. Basalt industries of Tafuna (AS-31150) and Pava'ia’I (AS-31-170), Tutuila Island, American Samoa. Archaeology in Oceania, 42(1): 33-40. doi:10.1002/j.1834-4453.2007.tb00014.x

Nadel, D., Rosenberg, D., Shtober Zisu, N., \& Filin, S. 2011, The Nahal Galim/Nahal Ornit prehistoric flint quarry in Mt. Carmel, Israel. Eurasian Prehistory, 8(1-2): 51-66.

Olami, Y. 1984, Prehistoric Carmel. Israel Exploration Society, Jerusalem, 216 p.

Özbek, O. 2000, A prehistoric stone axe production site in Turkish Thrace: Hamaylitarla. Documenta Praehistorica, 27: 167-170.

Özbek, O. 2011. Primary and secondary raw material preferences in the Neolithic societies in Northwest Turkey in the production of Neolithic polished stone tools in north-west Turkey. In: Stone Axe Studies III (Davis, V., \& Edmonds, M., Eds.), Oxbow Books, Oxford: p. 217-229. 
Özbek, O., \& Erol, K. 2001. Etude pétrographique des haches polies du Hamaylitarla et Fenerkaradutlar (Turquie). Anatolia Antiqua, 9: 1-7. (in French) ("Petrographic study of polish axes of Hamaylitarla and Fenerkaradutlar (Turkey)"). doi:10.3406/anata.2001.953

Pétrequin, P., \& Pétrequin, A.M. 1993, From polish stone tool to the sacred axe. The axes of the Danis of Irian Jaya, Indonesia. In: The Use of Tools by Human and Non-Human Primates (Berthelet, A., \& Chavaillion, J., Eds.), Clarendon Press, Oxford: p. 359-377. doi:10.1093/acprof:oso/9780198522638.001.0001

Pétrequin, P., Pétrequin, A.M., Jeudy, F., Jeunesse, C., Monnier, J.L., Pelegrin, J., \& Praud, I. 1998, From the raw material to the Neolithic stone axe: production processes and social context. In: Understanding the Neolithic of Northwestern Europe (Edmonds, M., \& Richards, C., Eds.), Cruithne Press, Glasgow: p. 277-311.

Quintero, L. A., \& Wilke, P. J. 1995, Evolution and economic significance of naviform coreand-blade technology in the southern Levant. Paléorient, 21(1): 17-33. doi:10.3406/paleo.1995.4607

Raban, A. 1999, Map of Mishmar Ha-'Emeq. Archaeological Survey of Israel, Israel Antiquity Authority, Jerusalem, 220 p.

Rhoads, J.W., \& Mackenzie, D.E. 1991, Stone axe trade in prehistoric Papua: the travels of Python. Proceedings of the Prehistoric Society, 57(2): 35-49. doi:10.1017/s0079497x00004497

Risch, R. 2011, Social and economic organization of stone axe production and distribution in the western Mediterranean. In: Stone Axe Studies III (Davis, V., \& Edmond, M., Eds.), Oxbow Books, Oxford and Oakville: p. 99-118.

Ronen, A., \& Davis, M. 1970, Un atelier de taille Neolithique au Mt. Carmel - le point 355 Z. L'Anthropologie, 74: 161-194. (in French) (“A Neolithic knapping workshop at Mt. Carmel - point 355 Z”).

le Roux, C.T. 1998, Specialized production, diffusion, and exchange during the Neolithic in Western France: the example of polished stone axes. In: Understanding the Neolithic of North-Western Europe (Edmonds, M., \& Richards, C., Eds.), Cruithne Press, Glasgow: p. 370-384.

Rosen, S. 1997, Lithics After the Stone Age: A Handbook of Stone Tools from the Southern Levant. Altamira Press, Walnut Creek, 184 p.

Rosen, S. A., \& Schneider, J. S. 2001, Early Bronze Age milling stone production and exchange in the Negev: preliminary report. Journal of the Israel Prehistoric Society, 31: 201-212.

Rosenberg, D. 2008. Serving meals making a home - The PPNA limestone vessel industry of the Southern Levant and its importance to the Neolithic Revolution. Paléorient, 34(1): 23-32. doi:10.3406/paleo.2008.5231

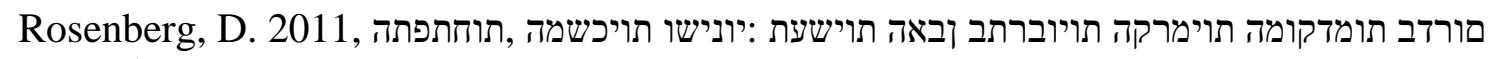
טנאבלה Ph.D. thesis, University of Haifa, Haifa, 572 p. (in Hebrew) ("Development, continuity and change: the stone industries of the early ceramic-bearing cultures of the Southern Levant”) 
Rosenberg, D. in press. The stone assemblage of Hagoshrim - Continuity and change in the Neolithic of northern Israel. In: Hagoshrim (Getzov, N., ed.), IAA Reports, Israel Antiquities Authority, Jerusalem, 55 p.

Rosenberg, D., Etzion, N., Ronen, A., \& Kaufman, D. 2009, Daliyat el-Carmel 3 - A flint bifacial tools workshop on Mount Carmel: Preliminary account. Neo-Lithics, 2(09): 3135 .

Rosenberg, D., \& Gluhak, T. 2015, Trade me an axe? Interpretive challenges of the distribution and provenance of Neolithic basaltic bifacial tools in Israel. Antiquity, 90(349): 1-16. doi:10.15184/aqy.2015.191

Rosenberg, D., \& Gopher, A. 2010, Food processing tools and other groundstone implements from Gilgal I and Gilgal III. In: Gilgal: Early Neolithic Occupations in the Lower Jordan Valley. The Excavations of Tamar Noy (Bar-Yosef, O., Goring-Morris, A.N., \& Gopher, A., Eds.), American School of Prehistoric Research Monograph Series, Oxbow, Oxford: p. 139-175.

Rosenberg, D., Kaufman, D., Yeshurun, R., \& Weinstein-Evron, M. 2012, The broken record: The Natufian groundstone assemblage from el-Wad Terrace (Mount Carmel, Israel) attributes and their interpretation. Journal of Eurasian Prehistory, 9(1-2): 93-128.

Rosenberg, D., \& Nadel, D. 2009, Prehistoric flint quarries and workshops in Mount Carmel The Nahal Galim/Nahal Ornit complex. The Quarry, 4(2): 5-12.

Rosenberg, D., Nadel, D., \& Ronen, A. 2011, Ein Qedem 2 - A Kebaran site in Nahal Galim, Mount Carmel, Israel. Documenta Prehistorica, 38: 231-239. doi:10.4312/dp.38.18

Rosenberg, D., \& Shimelmitz, R. 2010, Giv'at Kipod - a basalt quarry and a workshop for the production of bifacial tools in Israel. The Quarry, 5: 7-14.

Rosenberg, D., Shimelmitz, R., \& Nativ, A. 2008, Basalt bifacial tools production in the Southern Levant: A glance at the quarry and workshop site of Giv'at Kipod, Israel. Antiquity, 82: 367-376. doi:10.1017/S0003598X00096861

Ross, A., Anderson, B., \& Campbell, C. 2003, Gunumbah: archaeological and aboriginal meanings at a Quarry site on Moreton Island, Southeast Queensland. Australian Archaeology, 57: 75-81. doi:10.1080/03122417.2003.11681764

Samzun, A. 1994, Le mobilier en pierre. In: Le Site de Hatoula en Judée Occidentale, Israël (Lechevallier, M., Ronen, A., Eds.), Mémoires et Travaux du Centre de Recherche Français de Jérusalem 8, Association Paléorient, Paris: p. 193-226. (in French) ("The ground stones assemblage”)

Schortman, E.M., \& Urban, P.A. 2004, Modeling the roles of craft production in ancient political economies. Journal of Archaeological Research, 12(2): 185-226. doi:10.1023/B:JARE.0000023712.34302.49

Schyle, D. 2007, Ramat Tamar and Metzad Mazal. The Early Neolithic Economy of Flint Mining and Production of Bifacials Southwest of the Dead Sea. Ex Oriente, Berlin, $224 \mathrm{p}$.

Shafer, H. J., \& Hester, T. R. 1991, Lithic craft specialization and product distribution at the Maya site of Colha Belize. World Archaeology, 23(1): 79-97. doi:10.1080/00438243.1991.9980160

Shea, J.J. 2013, Stone Tools in the Paleolithic and Neolithic Near East. Cambridge University Press, Cambridge, 422 p. 
Shimelmitz, R. 2009, Variability in the specialized Canaanean blade production of the Early Bronze Levant. In: Techniques and People (Rosen, S., \& Roux, V., Eds.), Le Centre de Recherche Français à Jérusalem, Jerusalem: p. 135-156.

Shimelmitz, R., Barkai, R., \& Gopher, A. 2000, A Canaanean blade workshop at Har Haruvim, Israel. Tel Aviv, 27(1): 3-22. doi:10.1179/tav.2000.2000.1.3

Shimelmitz, R., \& Mendel, S. 2008, A Chalcolithic workshop for the production of blades and bifacial tools at Khirbet Yoah, the Manasseh Hills. Journal of the Israel Prehistoric Society, 38: 229-256.

Shimelmitz. R., Rosenberg, D., \& Nativ, A. 2005, Giva’t Kipod: A basalt quarry and workshop for the production of bifacial tools in the Manasseh Hills, Israel. Neo-Lithics, 1(5): 9-12.

Taçon, P. 1991, The power of stone: Symbolic aspects of stone use and tool development in Western Arnhem Land, Australia. Antiquity, 65(247): 192-207. doi:10.1017/s0003598x00079655

Thomas, J., \& Tilley, C. 1993, The axe and the Torso: Symbolic structures in the Neolithic of Brittany. In: Interpretative Archaeology (Tilley, C., Ed.), Berg, Oxford: p. 225-324. doi:10.5040/9781474214995.ch-006

VanPool, T.L., \& Leonard, R.D. 2002, Specialized ground stone production in the Casas Grandes region of Northern Chihuahua, Mexico. American Antiquity, 67(4): 710-730. doi:10.2307/1593800

Vardi, J. 2015, Larnite-Bearing Rock - the discovery of a new source of raw material in the production of Neolithic and Chalcolithic bifacial tools. Archaeometry, 57, Suppl. 1: 2035. doi:10.1111/arcm.12131

Vaughn, K. J. 2006, Craft production, exchange, and political power in the Pre-Incaic Andes. Journal of Archaeological Research, 14: 313-344. doi:10.1007/s10814-006-9007-2

Wilson, L. 2007, Understanding prehistoric lithic raw material selection: application of a gravity model. Journal of Archaeological Method and Theory, 14(4): 388-411. doi:10.1007/s10816-007-9042-4

Wreschner, E. 1963, Un atelier de taille dit "Givat Mikhal". Bulletin Société Belge d'Anthropologie et de Préhistoire, 73: 197-211. (in French) (“A knapping workshop "Givat Mikhal"”)

Wright, K. 1993, Early Holocene ground stone assemblages in the Levant. Levant, 25(1): 93111. doi:10.1179/lev.1993.25.1.93

Yerkes, R.W., Barkai, R., Gopher, A., \& Bar-Yosef, O. 2003, Microweare analysis of early Neolithic (PPNA) axes and bifacials tools from Netiv Hagdud in the Jordan Valley, Israel. Journal of Archaeological Science, 30(8): 1051-1066. doi:10.1016/s03054403(03)00007-4 